\title{
Aleksander Wirpsza
}

Uniwersytet Warszawski szaruga@warszawa.home.pl

\section{Tożsamość Międzymorza - Zachód}

Prezentowany tekst jest wprowadzeniem do rozprawy o formowaniu się Międzymorza, którego kraje w XIX oraz XX wieku pozbawione były bytu politycznego i suwerenności. Stało się to przyczyną uformowania specyficznej tożsamości w napięciu między demokracją Zachodu i samodzierżawiem Rosji. Społeczności Międzymorza nie brały zatem udziału w kształtowaniu struktur nowożytnych państw narodowych w XIX stuleciu. Tekst wprowadza w problematykę włączania krajów Międzymorza w zachodni system polityczny po przemianach 1989 roku.

Słowa kluczowe: Międzymorze, tożsamość kulturowa, tożsamość narodowa, procesy kulturowe

\section{Wprowadzenie}

Międzymorze - obszar Europy obejmujący kraje położone w trójkącie, którego „wierzchołki” wyznaczają Adriatyk, Bałtyk i Morze Czarne - jest zjawiskiem historycznym ukształtowanym w dobie powstawania nowożytnych państw narodowych w XIX stuleciu i istniejącym do czasu ,jesieni ludów” roku 1989. W całym tym okresie owe kraje - wyjąwszy Czarnogórę - pozbawione były bytu politycznego, a zatem i politycznej podmiotowości, pozostając pod władztwem potęg okupacyjnych: Turcji, Rosji i Austro-Węgier, później zaś Sowietów. Dotyczy to krajów bałkańskich, z Grecją włącznie, środkowoeuropejskich oraz bałtyckich, wraz z Finlandią. Można zasadnie przyjąć, 
że ich doświadczenia wytworzyły na tym obszarze specyficzną tożsamość będącą skutkiem swoistego wyłączenia $z$ historii polegającego na braku suwerenności lub przynajmniej jej ograniczeniu przez dominujące potęgi. Przy czym przyjąć należy, że dla wielu z nich okres między pierwszą i drugą wojną światową, gdy ich byt polityczny zdawał się trwały, był zbyt krótki, by pozwolić im na zdobycie statusu partnerskiego zwłaszcza wobec mocarstw, które od kongresu wiedeńskiego w 1815 roku decydowały o ich losach. Odzyskanie niepodległości czy jej pozyskanie po rozpadzie w 1918 roku trzech cesarstw europejskich i po upadku imperium osmańskiego okazało się stanem przejściowym, ziemie te zaś nadal pozostały obszarem walki o strefy wpływów - teraz między Rosją (występującą jako Związek Sowiecki) a Zachodem budującym nowy typ wspólnoty kontynentalnej. Najkrwawszy epizod owych zmagań miał miejsce w czasie wojny domowej w Grecji w latach 1944-1949. Specyficzny status udało się wynegocjować Finlandii za cenę drastycznie ograniczonej suwerenności. Wreszcie specyficzną sytuację zyskały - po zerwaniu sojuszu z Sowietami - kraje wchodzące w skład Jugosławii.

Ważnym czynnikiem kształtującym tożsamość Międzymorza jest zróżnicowanie wpływów religijnych. O ile na Zachodzie dominował katolicyzm i protestantyzm, w Rosji prawosławie, w Turcji zaś islam, o tyle obszar Międzymorza stanowił w decydującym o jego tożsamości okresie swoistą mozaikę religijną, w której - obok obecności do czasu Zagłady judaizmu - prawosławie, katolicyzm i protestantyzm w wielu krajach wzajemnie się przenikały (efektem tego było m.in. powstanie obrządku greckokatolickiego), na Bałkanach zaś zaznaczył się silny wpływ islamu. Zarazem też instytucje religijne - inaczej, niż to się działo w państwach zachodnich - odgrywały istotną rolę w kultywowaniu tradycji narodowej kultury. Przy tym nie bez znaczenia pozostało na tym obszarze doświadczenie dominacji komunistycznej nacechowanej niekiedy brutalną walką z praktykami i instytucjami religijnymi, które prześladowano i których obrona była w tym okresie jedną z najbardziej angażujących, choć często niejawnych form społecznej aktywności. 
Czynnik ten często jest przez Zachód niedostrzegany, niejednokrotnie zaś - ze względu na ukształtowaną praktykę rozdziału państwa i Kościoła - traktowany jako przeszkoda w upowszechnianiu w krajach Międzymorza zasad demokracji liberalnej ów rozdział respektującej. Jednocześnie należy podkreślić, że owe zasady wciąż traktowane są przez instytucje religijne krajów Międzymorza jako zagrożenie dla wolności praktyk wyznaniowych i dążenie do eliminacji religii z życia społecznego, w szczególności zaś uszczuplania wpływu, jaki te instytucja zdobyły w czasach zniewolenia, gdy w dużej mierze nie tylko broniły wiary, lecz także tworzyły jedną z najważniejszych, choć na ogół tylko dyskretnie obecnych struktur wspólnotowych.

Pojęcie Międzymorza więc, funkcjonujące w polskiej myśli politycznej za sprawą koncepcji Józefa Piłsudskiego, przeżywające obecnie w Polsce publicystyczno-ideologiczny renesans, domaga się redefinicji. W niniejszej pracy będzie ono oznaczać obszar od Grecji po Finlandię powstały w wieku XIX, a obejmujący kraje,

- które w czasie kształtowania się nowożytnych państw narodowych pozbawione były politycznej suwerenności, a tym samym nie mogły stanowić podmiotów w polityce międzynarodowej;

- które w odróżnieniu od krajów Zachodu nie uczestniczyły w krucjatach XI-XIII stulecia, a tym samym nie wytworzyły świadectw tego doświadczenia w swej literaturze i nie uczestniczyły w formowaniu zakonów rycerskich;

- które cechował śladowy ruch w procesie reformacji, a zatem nie uczestniczyły $\mathrm{w}$ formacyjnym doświadczeniu Zachodu, jakim była wojna trzydziestoletnia, w wyniku której obowiązywała zasada cuius regio, eius religio;

- które nie były, jak większość państw zachodnich i Rosja oraz Turcja, krajami kolonialnymi;

- które w swojej myśli politycznej w mniejszym lub większym stopniu obecne są, odwołujące się do doświadczeń historycznych mity wielkości (Wielka Bułgaria, Księstwo Wielkomorawskie, Wielka Serbia, 
Wielkie Węgry itd.), a także wielkościowe aspiracje (Wielka Finlandia);

- których kultura naznaczona jest mniej lub bardziej silnym kompleksem niższości wobec Zachodu;

- których granice wyznaczane były w XIX i XX wieku przez mocarstwa zachodnie i Rosję, a nie w rezultacie traktatów bilateralnych z sąsiadami;

- które w XX wieku doświadczyły obu totalitaryzmów: nazistowskiego i komunistycznego;

- na obszarze których w XIX i XX stulecia dochodziło do buntów przeciwko obcej dominacji, powstań i innych wystąpień o charakterze narodowowyzwoleńczym, co w krajach Zachodu stanowiło zjawiska incydentalne.

Specyfika historycznego doświadczenia sprawia, że obecnie, w trakcie procesów integracyjnych w Europie zapoczątkowanych utworzeniem Wspólnoty Węgla i Stali, a w chwili obecnej poszerzającej swój obszar Unii Europejskiej, stanowią one dla krajów „starej Unii” partnerów wobec Brukseli nieufnych, często niepojmujących wagi systemu prawnego i związanych z nim procedur utrwalających zasady liberalnego państwa prawa lub otwarcie przeciw tym zasadom występujących, zarazem też przywiązujących szczególną wagę do kwestii politycznej suwerenności i domagających się respektowania swej odmienności w tej mierze. Nie bez znaczenia są tu na poły aroganckie, choć zapewne dyktowane dobrą wolą wypowiedzi zachodnich intelektualistów, takich choćby jak słowa Jeana Marie Domenacha komentujące przemiany po roku 1989:

W 1989 roku w Polsce, na Wegrzech $i$ w Czechosłowacji nastapit koniec systemu jednopartyjnego, w Berlinie zawalit się mur, a w Rumunii zwyciężyło powstanie społeczeństwa przeciw dyktaturze. W ten sposób Europa Środkowa zostaje przywrócona historii i raz jeszcze decydujacy impuls do działania daty nam narody zniewolone. Proces nie jest zakończony. Choroba może się udzielić samej Rosji, która - wyrzekając się imperium opartego na dawno już pogrzebanej ideologii marksistowsko-leninowskiej - mogłaby uszczelnić swoje granice i próbować, korzy- 
stajac z odprężenia, odbudować swoją siłę, powierzając kraje satelickie troskliwej opiece Zachodu'.

Nie ulega wątpliwości, że niemal na pewno część środkowoeuropejskich odbiorców tego rodzaju deklaracji może odczytywać słowa mówiące o „troskliwej opiece” jako zapowiedź swego rodzaju manipulacji politycznej zmierzającej do jakiegoś podporządkowania ich krajów kolejnemu, miękkiemu, ale jednak dyktatowi mającemu na celu ich ubezwłasnowolnienie.

W kontekście słów Domenacha warto też postawić pytanie zasadnicze: co w jego - a także innych intelektualistów tej formacji - oznacza „przywrócenie” narodów historii, a wreszcie co znaczy sama „historia”, jakie jest jej pojmowanie? Otóż wydaje się, że obecność w historii rozumiana jest tutaj jako uczestnictwo w procesie formowania współczesnej demokracji liberalnej uformowanej na fundamencie państwa prawa budowanym jako kontynuacja zasad prawa rzymskiego, z czego by wynikało, że społeczności i kraje w tym procesie nieuczestniczące $\mathrm{z}$ definicji pozostają poza historią. To wszakże nie znaczy, że są pozbawione dziejów, które bądź wpisują się w ten proces, bądź ich trwanie i przemiany, jakim podlegają tworzą historię alternatywną, lecz przecież do bólu realną, co w jakiejś mierze jest - przynajmniej w ciągu ostatnich dwóch stuleci - udziałem ludów zamieszkujących przestrzenie Międzymorza. Proces dostosowywania tych dziejów do historii Zachodu siłą rzeczy nie może być wolny od konfliktów, których skutki w chwili obecnej trudno określić.

\section{Europa}

Każdy, kto spogląda na mapę, bez trudu wyodrębni obszar z jednej strony wyznaczany przez pasmo Uralu, z drugiej przez północne wybrzeża Morza Czarnego i Morza Śródziemnego, wreszcie przez linię

${ }^{1}$ Zob. J. M. Domenach, Europa: wyzwanie dla kultury, przeł. H. Sikorska, Warszawa 1992. 
brzegową Atlantyku i Morza Północnego, aż po Ocean Arktyczny. Z punktu widzenia geograficznego nie jest oczywistością wyjmowanie tego terytorium z całości, jaką współtworzy z Azją. W istocie można traktować Europę - a przynajmniej jej część - jako półwysep niespecjalnie wyodrębniony przez właściwości klimatyczne czy geologiczne, które, choć zróżnicowane, nie określają jego odrębności, a płynność stosunkowo obszernego lądowego połączenia z Azją wyraźnie wykazuje sztuczność wydzielenia obu kontynentów stanowiących w zasadzie tylko umowne części spoistego lądowego terytorium.

Gdy z kolei oglądamy mapę polityczną owej całości, nie mamy wątpliwości, że Federacja Rosyjska - największe terytorialnie państwo kuli ziemskiej - należy tyleż do Europy, co do Azji. Nie sposób też nie zauważyć, że pograniczny charakter mają kraje Kaukazu - Gruzja, Armenia, Azerbejdżan, także Czeczenia. Ale, rzecz jasna, mapa polityczna Europy, w odróżnieniu od mapy fizycznej, uderza swą zmiennością. Rzut oka na kolejne karty atlasu historycznego kontynentu ukazuje niezwykle interesującą dynamikę jego przemian: w różnych okresach państwa wyłaniają się z niebytu, znikają, pojawiają się znowu, rozrastają i kurczą. Dotyczy to w szczególności obszaru rozciągającego się między Bałtykiem, Morzem Czarnym oraz Adriatykiem, podczas gdy zarówno zachodnie przestrzenie, jak i terytorium wschodnie cechuje względna stabilność terytorialna położonych nań państw. Jedno nie ulega wątpliwości - w ciągu ostatnich piętnastu stuleci kraje europejskie stosunkowo często zmieniały swe kształty i można powiedzieć, że proces ten wciąż jeszcze się nie zakończył, a w każdym razie przyjęcie, że w tej sferze sytuacja nie będzie ulegała zmianie wydaje się nie do końca uzasadnione.

Warto też zauważyć, że Europa widziana z zewnątrz - czy to z perspektywy Buenos Aires, czy z Sydney, Waszyngtonu lub Moskwy - jest swego rodzaju osobliwością, której specyfika polega na tym, że relatywnie niewielki obszar zapełnia mnogość skupisk narodowych posługujących się w swoich krajach odmiennymi językami. Zarazem jednak, zwłaszcza dla mieszkańców ziem amerykańskich, ale także Australii, istotne znaczenie ma traktowanie Europy jako „starego kontynentu”, 
swoistej „dawnej ojczyzny”, z którą łączą ich więzy pokrewieństwa będące źródłem bądź nostalgii, bądź resentymentów. Z pewnością - przyjmując perspektywę historyczną - wciąż jeszcze jest Europa jednym z najważniejszych punktów odniesienia w systemie relacji kulturalno-politycznych, choć bez wątpienia także w tej materii sytuacja się zmienia, co niezwykle trafnie jeszcze pod koniec lat siedemdziesiątych XX wieku pochwycił Jacek Bocheński.

Wśród inteligencji polskiej jeszcze mało kto dostrzega, że środkiem ciężkości świata przestat być Paryż, że - co więcej - przestaja być nimi także Waszyngton i Moskwa, że ów środek jest już w miejscu niezbyt określonym, a niestychanym, jak gdyby w Azji, jak gdyby w Ameryce Łacińskiej, może $w$ afrykańskim buszu.

Nie znaczy to, że „biała cywilizacja” dogorywa i może nas nie obchodzić. Skończyly się imperia kolonialne (z wyjątkiem rosyjskiego na dwóch kontynentach), ale to właśnie „,biała cywilizacja” dała impuls i kierunek rozwojowi Trzeciego Świata, poczawszy od Japonii. Europa nie ma władzy nad reszta kuli ziemskiej, lecz ta reszta, chcac nie chcac, naśladuje , biała cywilizację”, bo żadnej innej nie może $e^{2}$.

Mechanizm jest tutaj zapewne taki sam jak ten, który funkcjonował po opanowaniu przez barbarzyńców Imperium Romanum. Mniej lub bardziej dyskretna obecność Europy w kulturze globalnej nie oznacza jednak jej zamknięcia na dopływy z zewnątrz nawet w dziedzinach tak radykalnie sprofesjonalizowanych, jak matematyka czy fizyka, począwszy od zdefiniowania zera, co uczynione zostało w ogłoszonym w 408 roku traktacie Lokavibhaaga, po współczesne problemy filozofii, o czym interesująco pisze fizyk niemiecki Carl Friedrich von Weizsäcker:

Teoria jest, tak to odczuwam, szczególnym dziełem sztuki kultury zachodniej, odróżniającym ją od wszystkich innych kultur. Hindusi i Japończycy powiedzieli mi: „, Siła i granica waszej kultury jest panowanie logiki arystotelesowskiej"”.

${ }^{2}$ Zob. J. Bocheński, Niepodległość wśród ludzkości, „Zapis” 1978, nr 8.

${ }^{3}$ Zob. C. F. Weizsäcker, Czas, fizyka, metafizyka, przeł. K. Napiórkowski [w:] Człowiek w nauce współczesnej. Rozmowy w Castelgandolfo, red. K. Michalski, Paris 1988. 
Być może żywotność Europy ma swe źródło w jej otwartości, zdolności asymilowania dopływów zewnętrznych - zarówno idei, jak ludzi w jej dynamice. Jak bowiem zauważa Jan Józef Szczepański w reportażu poświęconym kulturom indiańskim: „Dawne kultury statyczne umierały lub upadały nagle z powodu nadmiernej jednorodności, z powodu niedostatku opcji, pobudzających proces poszukiwań i wyboru"4. Podobną myśl odnajdujemy także w wierszu Konstandinosa Kawafisa Czekajac na barbarzyńców:

Dlaczego wszystkich nagle ogarnąt niepokój?

Skad zamieszanie? (Twarze jakże spoważniaty.)

Dlaczego tak szybko pustoszeja ulice

i place? Wszyscy do domu wracaja zamyśleni.

Dlatego że noc zapadła, a barbarzyńcy nie przyszli.

I ktoś, kto właśnie wrócił od granicy,

mówi, że już nie ma żadnych barbarzyńców.

Bez barbarzyńców - cóż poczniemy teraz?

Ci ludzie byli jakimś rozwiąaniem ${ }^{5}$.

Warto podkreślić, że podwaliny współczesnej Europy położyli właśnie barbarzyńcy, przybysze z Azji, głównie Germanie i Słowianie. Można zaryzykować tezę, że początek Europie dało obalenie 4 września 476 roku cesarza Romulusa Augustulusa przez barbarzyńskiego wodza Odoakera. Zdobywcy wszakże stali się spadkobiercami imperium, przejmując $\mathrm{w}$ końcu jego religię i prawa - był to proces długotrwały, zakończył się jednak ustanowieniem Europy jako wspólnoty chrześcijańskiej, choć samo chrześcijaństwo jako obowiązująca w cesarstwie religia, było wówczas zjawiskiem stosunkowo nowym, wprowadzonym przez Konstantyna w roku 313 - wcześniej, w roku 301 chrześcijaństwo jako religię państwową wprowadził król Armenii Tridates III.

\footnotetext{
${ }^{4}$ Zob. J. J. Szczepański, Nasze nie nasze, Kraków 1984.

${ }^{5}$ Zob. K. Kawafis, Wiersze zebrane, przeł. Z. Kubiak, Warszawa 1992.
} 
Istotnym elementem tego niepozbawionego dramatyzmu ,zderzenia cywilizacji” Rzymu i barbarzyńców było spotkanie kultury oralnej z piśmienną. Analizując ten styk w sferze kodyfikacji praw przybyszów, pisze Karol Modzelewski:

W procesie kodyfikacji chrześcijańska kultura słowa pisanego spotkała się z tradycyjna kultura oparta na przekazie ustnym. Byto to spotkanie naznaczone konfliktem, choćby dlatego, że tradycja ustna przekazywała prawo zwyczajowe w połączeniu z mitami $i$ wartościami, których chrześcijaństwo nie mogło akceptować. [...] Nic dziwnego, że spisy prawa poszczególnych ludów znacznie różnity się między soba. W każdym jednak wypadku pisemna kodyfikacja oznaczała, że w systemie norm prawnych nie ma już miejsca dla Wotana, Tiwaza, Thora, Peruna ani Welesa. Chrystus nie mógt przejąć ich roli, gdyz byt z innego świata. Następowało więc rozdzielenie prawa od sacrum. Była to głęboka zmiana, wykraczająca poza wasko pojmowana kwestię legitymizacji i sięgajaca kulturowych podstaw systemu norm społecznych ${ }^{6}$.

Również barbarzyńcy wnosili nową jakość do systemu prawnego: „Germańscy przybysze wnieśli do rzymskiej Europy tzw. zasadę osobowości praw i nadali jej wysoką rangę ustrojową. Zgodnie z ową zasadą każdy wolny człowiek miał żyć i być sądzony według prawa swojego macierzystego plemienia"?.

Świat pisma w nowej, postrzymskiej Europie był w dominującej mierze światem języka łacińskiego. Przy tym należy podkreślić, że chodzi tu jedynie o jej część zachodnią powstałą po rozdziale ziem Imperium Romanum w roku 395 na obszar wschodni (Bizancjum) i zachodni (Rzym). W pierwszym z nich dominowała greka, w późniejszym okresie zaś ważną rolę odegrał język cerkiewnosłowiański będący na wielu obszarach cesarstwa językiem liturgicznym.

Bez wątpienia zarówno religia, jak język łaciński stanowiły fundament jedności europejskiego Zachodu, przynajmniej gdy chodzi o ludzi

\footnotetext{
${ }^{6}$ Zob. K. Modzelewski, Barbarzyńska Europa, Warszawa 2004.

${ }^{7}$ Ibidem.
} 
piśmiennych, litterati, głównie, w początkowej fazie, ludzi Kościoła, później wszystkich wykształconych. Przez pewien czas wszakże - czego dowodzą choćby Legendy Hroswithy z Gandersheim (960-1000) - w piśmiennictwie tym następowało przemieszanie wątków mitologii antycznej i chrześcijańskiej. Dziedzictwo antyku z pewnością przenikało w przestrzeń świata chrześcijańskiego nawet we wczesnym średniowieczu. I ta ciągłość wydaje się mieć znaczenie decydujące dla formowania europejskiej tożsamości. Zarazem jednak konstatacja owej ciągłości skłania do myśli o tym, że podejmujący czy przejmujący spadek po Rzymianach barbarzyńcy w pewien sposób, pozostając zdobywcami, zostali, poprzez rezygnację czy odstępstwo od własnych mitów i tradycji - o całkowitym zapomnieniu jednak mowy być nie może: echa tej tradycji wciąż jeszcze bywają słyszalne nie tylko w folklorze, także w literaturze - podporządkowywali się zwyciężonym. Nie sposób przy tym nie wspomnieć o tym, że wiele elementów tradycji „nowych” Europejczyków - niezależnie od stopnia gorliwości w przyjmowaniu chrześcijaństwa - przez długi czas wiodło swój żywot poza pismem, w ludowej kulturze oralnej, przy czym im dalej na wschód, tym te podskórnie obecne wątki były trwalsze, wchodząc w często skomplikowane związki z kulturą warstw oświeconych. Ale też, jak na to wskazuje Aron Guriewicz, swoiste przenikanie się chrześcijaństwa i elementów kultury ludowej miało swe źródło we wschodnich obszarach kontynentu. Analizując treść średniowiecznych żywotów świętych, podkreśla:

Święty, to najpopularniejszy bohater średniowiecznego społeczeństwa, jego heroiczny czyn jest największym czynem, jakiego można dokonać na ziemi. To, że ten bohaterski przejawiat się w oderwaniu od świata, w stużeniu sprawom tamtego świata, być może najwyraźniej świadczy o głębi przemian świadomości społecznej w porównaniu z epoka barbarzyństwa, z jego heroika, i epoka antyczności, z jej kultem ciała, męstwa fizycznego. Ale zarazem święci musieli odpowiedzieć na powszechne i nie do przezwyciężenia zapotrzebowanie na cud. Święty zawsze $i$ wciąz byt cudotwórca, lekarzem, zdolnym wybawić swych czcicieli od naturalnych ii społecznych niedoli. Poszczególni przedstawiciele ducho- 
wieństwa od czasu do czasu wypowiadali się przeciwko nadmiernemu, ich zdaniem, rozpowszechnianiu się kultu świętych, czczeniu relikwii, widzac $w$ tym wskrzeszanie pogańskiego batwochwalstwa (na przykład Agobard z Lyonu, Klaudiusz z Turynu), jednak te wezwania nie odnosity poważniejszego skutku. Wbrew powtarzajacym się oświadczeniom dostojników Kościoła, że czasy dokonywania cudów to odległa przeszłość, masy potrzebowaty cudów, domagały się ich, i byty przekonane, że stanowia one nieodtaczna stronę życia ${ }^{8}$.

Zarazem warto pamiętać, że we wczesnych wiekach średnich - do końca X stulecia, w obszarze Cesarstwa Bizantyjskiego mamy do czynienia ze specyficznym procesem orientalizacji chrześcijaństwa, które zwięźle i w moim przekonaniu trafnie scharakteryzował Christopher Dawson:

Cesarstwo Bizantyjskie i jego kultura maja dwa aspekty. Z jednej strony reprezentuja ostatnia fazę wielkiego podboju i kolonizacji, który przeszczepit głęboko w serce Azji kulture grecka $i$ nad brzegami Indusu zbudowat miasta greckie. Okres tej wielkiej ekspansji począ słabnać na dtugo przed założeniem Cesarstwa Bizantyjskiego i stąd cała jego historię można rozpatrywać jako dlugie i uporczywe zmaganie się tylnej straży kultury greckiej z napierajacymi siłami Wschodu. Z drugiej wszakże strony można patrzeć na Cesarstwo Bizantyjskie jako na wynik procesu orientalizacji, który dogłębnie przeksztatcił charakter imperium rzymskiego ii kultury greckiej. Stare tradycje klasycznego miasta-państwa wraz z jego ideami wolności, obywatelstwa i niezależności ustapiły miejsca świętej monarchii w stylu wschodnim, a ośrodkiem życia ludności stat się Kościót i liturgia. Ortodoksyjna wiara stała się rzeczywista więzia społeczna, natomiast życie zakonne - antyteza politycznego życia greckiego miasta - było typowym składnikiem kultury bizantyjskiej ${ }^{9}$.

${ }^{8}$ Zob. A. Guriewicz, Problemy średniowiecznej kultury ludowej, przeł. Z. Dobrzyński, Warszawa 1987.

${ }^{9}$ Zob. Ch. Dawson, Szkice o kulturze średniowiecznej, przeł. J. Sułkowski, Warszawa 1966. 
Warto, zwłaszcza z dzisiejszej perspektywy, zwrócić uwagę na wartości wymienione przez Dawsona, a będące podstawowymi nośnikami przejętej z antyku tradycji: wolność, obywatelstwo oraz niezależność. Kwestią wszakże fundamentalną dla rozwoju w przyszłości poczucia odrębności europejskiej był przełom monoteistyczny, wskutek którego przewartościowaniu uległy - bez wątpienia w pierwszej fazie wśród elit, później w coraz szerszych kręgach - związki społeczne oparte na wielowyznaniowości. Tu pierwszorzędną rolę odegrało chrześcijaństwo zadekretowane w Imperium Romanum przez Konstantyna w IV stuleciu. Wcześniej obecny na terenie Cesarstwa judaizm, którego początki sięgają II tysiąclecia p.n.e., po zajęciu obszarów izraelskich przez Rzym w roku 63 p.n.e., później zaś, po zburzeniu Jerozolimy przez Hadriana $\mathrm{w}$ roku 135, przekształci się z religii kapłańskiej i świątynnej w religię Księgi (rabinacką) i przestał być wiarą ekspansywną. Konkurencję dla chrześcijaństwa stworzył natomiast powstały w roku 623 i oparty na wizjach Mahometa islam - siła jego ekspansji pozwalająca wyznawcom w ciągu stu lat przekształcić się z kilkudziesięcioosobowej grupy w społeczność obejmującą znaczne obszary Azji, Afryki Północnej i Europy uczyniła zeń, w starciu z chrześcijanami, jeden z ważniejszych czynników formujących szeroko pojmowaną wspólnotę europejską. Niewątpliwie też należy przyznać rację Normanowi Davisowi, gdy podkreśla, że

[i]slam wywart na Europe Wschodnia wptyw jeszcze bardziej bezpośredni niż na Europe Zachodnia. Jego pojawienie się oznaczało wytyczenie granic nowego, zwartego bytu, zwanego „światem chrześcijańskim”, którego najsilniejszym ośrodkiem miat przez pewien czas pozostać Konstantynopol. [...] Przede wszystkim jednak stworzyt przedmurze, w stosunku do którego można było zdefiniować europejska tożsamość. Nie tylko Karol Wielki, ale i Europa sq nie do pomyślenia bez Mahometa ${ }^{10}$.

${ }^{10}$ Zob. N. Davies, Europa. Rozprawa historyka z historia, przeł. E. Tabakowska, Kraków 1998. 
Bez wątpienia - choć proces ten postępował powoli - Europa drugiej połowy pierwszego tysiąclecia po Chrystusie stała się przede wszystkim wspólnotą chrześcijańską, przy czym nową wiarę przyjmowano, pomijając sposoby jej wprowadzania, z dwóch ośrodków: z Rzymu oraz z Bizancjum. Obie stolice obejmowały swymi wpływami kolejne obszary - na wschodzie Ruś czy Serbię bądź Bułgarię, na zachodzie Węgry, Czechy czy Polskę, przy czym strefy wpływów w początkowym okresie - do wieku X - w zasadzie nie były jasno określone, o czym zaświadcza podległa wschodniej, nie łacińskiej liturgii krótkotrwała potęga Księstwa Wielkomorawskiego, rozgromionego w 907 roku, w którym językiem urzędowym był starocerkiewnosłowiański. W tym czasie można określić cały ten obszar kontynentu pojęciem „Europy chrześcijańskiej”, w zasadzie religijnie niezróżnicowanej i budującej ponad polityczną wspólnotę złączoną wiarą we wspólnego Boga, dość jasnymi regułami relacji między władzą świecką, a dającą jej legitymację władzą kościelną. Nie będzie chyba nadużyciem określenie owej wspólnoty mianem unii religijnej, w ramach której trwała - głównie dynastyczna walka o panowanie nad określonymi jej obszarami i dla mieszkańców której zróżnicowanie etniczne czy narodowe nie odgrywało większego znaczenia, choć zapewne nie było sprawą obojętną to, kto, jaki zatem konkretnie władca jest poborcą podatków.

Procesy chrystianizacji poszczególnych ludów europejskich przebiegały z zadziwiającą prędkością. Przykładem mogą być Węgry:

Dramatyczny początek miała chrystianizacja na Wegrzech. Tu [...] rywalizowali ze soba przedstwiciele obrzadków wschodniego i zachodniego. O przyjęciu chrześcijaństwa z Rzymu przesadził władca Wegier, Wajk, który przeszedt do historii jako Stefan I (997-1038). Siła sttumit on opozycje pogańską i zwolenników wpływów bizantyjskich, a po dokonaniu bezwzględnej eksterminacji przywódcóø oporu podporządkowat też sobie dotychczas niezależne plemiona madziarskie ${ }^{11}$.

${ }^{11}$ S. Kwiatkowski, Średniowieczne dzieje Europy, Warszawa 2007, s. 341 
Owa jedność władzy kościelnej i świeckiej była w tym okresie równie istotna w przestrzeni wpływu Rzymu, jak i Bizancjum. U schyłku X stulecia wpływy Rzymu obejmowały w zasadzie pełen obszar dziś określany mianem Europy Zachodniej (prócz zajętych przez islam terenów na Półwyspie Iberyjskim oraz na Sardynii i Sycylii) oraz część obszarów nieco później przyjmujących chrześcijaństwo w Europie Wschodniej i Skandynawii, Bizancjum zaś część terenów basenu Morza Czarnego i Ruś Kijowską. Charakteryzując ten pierwszy, posługuje się jednak Jerzy Kłoczowski określeniem „Rzeczpospolita Chrześcijańska":

Wielka swoistościa „naszej” Europy, w ujęciu współczesnej historiografii, jest rola raczej społeczeństwa i Kościoła $w$ tworzeniu nowego porządku, aniżeli cesarstwa czy królestwa. Rodzaca się ,, Rzeczpospolita Chrześcijańska” była w założeniu bardziej rzeczapospolita samorzadna, z prawami gwarantowanymi dla każdego samorzadu. Odrzucano zdecydowanie zarówno absolutyzm teokracji (jak $w$ islamie), jak i cezaropapizm (podobnie jak w Bizancjum czy jeszcze za Karola Wielkiego) ${ }^{12}$.

Rodzi to oczywiście pytanie o zasady owej „samorządności”, nie mówiąc już o pojmowaniu tak podstawowej kategorii, jak „społeczeństwo". Z pewnością Kościół, kierujący się zasadą powszechności (katholikos), zmierzał do kreowania jednolitej czy niezróżnicowanej wspólnoty wiernych - jednym z istotnych środków prowadzących do tego celu było upowszechnienie języka łacińskiego, co jednak w żadnej mierze nie dotyczyło ogółu, a jedynie elit, a i to nie wszystkich, skoro Mechtylda, mniszka z Magdeburga zapisująca w XII wieku w Strumieniu światła swe wizje kończyła je stwierdzeniem: „Teraz mnie zwodzi mój niemiecki. Łaciny nie znam"13.

Łacinę natomiast na ogół znali książęta, królowie, a już z pewnością ich - by przywołać dzisiejszy termin - doradcy. Przy czym wprowa-

${ }^{12}$ Zob. J. Kłoczowski, Nasza tysiącletnia Europa, Warszawa 2010.

${ }^{13}$ Zob. Mechtylda z Magdeburga, Strumień światła, przeł. P. J. Nowak, TyniecKraków 1999. 
dzanie tego języka nie było wcale procesem bezkonfliktowym, na co wskazuje Julia Smith:

Pismo ogamiczne, podobnie jak runiczne, zostało przystosowane do użytku chrześcijańskiego, najdtużej, bo jeszcze $w X$ wieku, pozostajac w użytku w Szkocji. Zarzucenie go w Irlandii w VIII wieku i zastapienie tacina jako językiem mającym świadczyć o statusie osób świeckich stało się możliwe dopiero z chwila, gdy sama łacina przestała się kojarzyć z potężnymi sąsiadami na drugim brzegu Morza Irlandzkiego ${ }^{14}$.

Władcy, namaszczeni przez Kościół, powołani byli do panowania nad ludem, ale zarazem do dbałości o ów lud. Dla owej wspólnoty władzy i ludu posługiwano się łacińskim, wyniesionym z tradycji antycznej terminem patria, co raczej przywołuje i zapewne przywoływało wówczas takie określenia jak kraj czy ojczyzna, w dużo mniejszym zaś stopniu kojarzone być może z pojęciem państwa, szczególnie w tym rozumieniu, jakie pojawia się po średniowieczu. Zarazem też nie od rzeczy będzie przypuszczenie, że nawet powszechny w tym czasie termin regnum $\mathrm{z}$ trudem można by było traktować jako synonim państwa $\mathrm{w}$ dzisiejszym jego pojęciu.

Warto w tej kwestii przywołać uwagi z klasycznej już rozprawy Ernsta Kantorowicza:

Niemniej jednak $w$ jednym obszarze termin patria zachowat swoje petne, pierwotne znaczenie i dawne emocjonalne wartości, choćby tylko w przeniesionej i stranscendentalizowanej formie: byt to język Kościoła. Chrześcijanin, według nauki wczesnego Kościoła oraz Ojców Kościoła, stawat się obywatelem państwa, które istniało w innym wymiarze. Jego prawdziwa patria byto królestwo niebieskie, niebiańska Jerozolima. Ostateczny powrót do owej duchowej i wiecznej ,ojczyzny” byl, wedtug listów apostolskich, naturalnym pragnieniem pielgrzymującej po ziemi duszy chrześcijańskiej ${ }^{15}$.

${ }^{14}$ Zob. J. M. H. Smith, Europa po Rzymie. Historia kulturowa lat 500-1000, przeł. A. Cwojrak, Kraków 2008.

${ }^{15}$ Zob. E. H. Kantorowicz, Dwa ciała króla. Studium średniowiecznej teologii politycznej, przeł. M. Michalski, A. Krawiec, Warszawa 2007. 
Gdy mowa zatem o „Rzeczypospolitej Chrześcijańskiej”, należałoby ją chyba umiejscowić właśnie w owej transcendentnej patriae, a zatem w królestwie niebieskim aniżeli na ziemskim łez padole, którego porządek określają bardziej prawa i zasady tworzone przez ludzi niż prawa boskie. Można, oczywiście, widzieć w wyobrażeniach średniowiecznego człowieka wizję Civitas Dei - i zapewne wielu współczesnych tak to postrzegało - niemniej w ostatecznym rachunku sfera życia społeczno-politycznego niekoniecznie pozostawała w harmonii ze sferą życia religijnego, relacje między nimi bywały zaś skomplikowane, by wspomnieć tylko nałożoną na cesarza Henryka IV w 1076 przez papieża Grzegorza VII ekskomunikę.

Jeśli zaś chodzi o samorządność, to prawa, o których była mowa, były zapewne wynikiem samoorganizacji wspólnot wiejskich czy później także, zwłaszcza od wieku XII, miejskich, niż ich nadania aktem swobodnej decyzji zwierzchności czy to świeckiej, czy kościelnej. Jedno zaś zdaje się nie ulegać wątpliwości - niezależnie od charakteru owej samoorganizacji, w trakcie przemian zachodzących w społeczeństwach średniowiecza jeden spośród ideałów tradycji antyku - obywatelskość - został, zarówno w sferze politycznej, jak i religijnej, poddany daleko idącej redukcji. Europa powróci doń jednak po kilku stuleciach w zasadniczo zmienionych okolicznościach, gdy stanie się on wyzwaniem dla Zachodu.

Wschód wybrał inną drogę, co było skutkiem pierwszego z - jak dotychczas - najpoważniejszego rozłamu jedności Europy, który spowodowany został w roku 1054 przez wielką schizmę, czyli rozpad Kościoła na katolicyzm i prawosławie.

\section{Europa łacińska}

Rozłam między Kościołami grecko-bizantyjskim a łacińskim miał wiele przyczyn, wśród których warto zwrócić uwagę na dwie: pierwszą był spór o prymat w świecie chrześcijańskim, drugą zaś, na swój sposób donioślejszą i do dziś znaczącą, konkurencja o wpływy na ziemiach sło- 
wiańskich. Od ustalenia w roku 451 równoprawnej władzy patriarchów Bizancjum i papieży rzymskich kwestia przywództwa nie była ostatecznie przesądzona i powracała aż po połowę wieku XI. Jak podkreśla Henry Chadwick, opisując sytuację w połowie pierwszego tysiąclecia,

[p]apiestwo udzielało kluczowego wsparcia ewangelizacji $i$ cywilizowaniu pótnocnej Europy. Równocześnie ta tendencja do centralizacji zasiewała ziarna przyszłych problemów, wtedy kiedy zdawała się gwarantować rozwiazania. Po Leonie $i$ Grzegorzu papieże odziedziczyli poczucie odpowiedzialności za strzeżenie apostolskiej wiary $i$ rościli sobie prawo do sprawowania jurysdykcji nad wszystkimi Kościołami. Kościoły wschodnie, świadome swych starożytnych tradycji, zazwyczaj chętnie zaliczały biskupstwo Piotrowe do biskupstw, z którymi utrzymywaty komunię, ale nie uważały powszechnej jurysdykcji za rzecz pożadana ani możliwą ${ }^{16}$.

Konflikt z połowy XI stulecia nie należał zatem do wydarzeń wyjątkowych i ma rację Stefan Kwiatkowski, gdy pisze, że wydarzenie to ,zostało przez współczesnych zrozumiane jako mało znaczący incydent" ${ }^{17}$. Niemniej różnice między Rzymem a Bizancjum miały coraz bardziej wyrazistą postać, szczególnie nasiliły się w okresie panowania cesarza Henryka III, który, dążąc do reformy Kościoła, ingerował nawet w wybór papieży. W efekcie doszło w Konstantynopolu do zamknięcia kościołów łacińskich, na co protegowany cesarza, papież Leon IX odpowiedział, wysyłając swego legata, który wkroczył do Haga Sofia, gdzie złożył bullę nakładającą ekskomunikę na patriarchę Michała Cerulariusza, co spowodowało ostra reakcję - zwołanie synodu, spalenie bulli papieskiej i obłożenie klątwą Kościoła rzymskiego. Wszakże decydującą rolę w utrwaleniu podziału miało wydarzenie nieco późniejsze, jakim było ogłoszenie w 1075 roku przez papieża Grzegorza VII Dictatus Papae, w którym zadekretowana została władza papieska nad Kościołem

${ }^{16}$ Zob. H. Chadwick, Kościót w epoce wczesnego chrześcijaństwa, przeł. A. Wypustek, Warszawa 2004.

${ }^{17}$ Zob. S. Kwiatkowski, Średniowieczne dzieje Europy, Warszawa 2006. 
i całym światem. Wśród 27 tez składających się na ten dokument mowa też o tym, że jedynie papieżowi „wolno władcami rozporządzać a więc i cesarzy z tronu składać”. Punktem centralnym sporu z cesarzem Henrykiem IV była kwestia nominowania biskupów - po uznaniu przez cesarza nielegalności władzy papieskiej został on obłożony ekskomuniką. I choć zdawać się mogło, że spór o inwestyturę rozstrzygnięty został zwłaszcza po ukorzeniu się Henryka IV przed papieżem pod murami Canossy - rzecz po niewielu latach zakończyła się kompromisem. Niemniej, choć rzecz dotyczyła przede wszystkim sprawy urzędów kościelnych, z historycznego punktu widzenia ma swoje znaczenie ze względu na to, że była pierwszą tego rodzaju próbą sił między władzą świecką i duchowną. Z punktu widzenia natomiast jedności Europy Dictatus oznaczał, za sprawą ogłoszenia papieża rzymskiego jedynym zwierzchnikiem Kościoła, na co Bizancjum zgodzić się nie mogło, ostateczny rozłam.

Jego pogłębienie nastąpiło w efekcie podjęcia przez władców i rycerstwo Zachodu pod patronatem Kościoła serii wypraw krzyżowych, których celem było wyzwolenie zdobytej przez muzułmanów Jerozolimy i zapewnienie wiernym dostępu do Ziemi Świętej. Pierwsza z tych wypraw - poprzedzona swego rodzaju ludowym pospolitym ruszeniem - rozpoczęła się w roku 1096, ostatnia zaś miała miejsce w roku 1270. Jednym z istotnych pozytywnych skutków, jakie przedsięwzięcia te przyniosły Europie, był rozwój miast włoskich, przede wszystkim Wenecji, a nade wszystko rozbudowanie żeglugi morskiej, co w późniejszym okresie przyczyniło się do europejskiej ekspansji kolonialnej. Z punktu widzenia relacji między Rzymem a Bizancjum najważniejsze wydają się wydarzenia związane z IV krucjatą w latach 1202-1204, zakończonej oblężeniem i zdobyciem przez krzyżowców - których pierwotnym celem był Egipt - Konstantynopola. ,Złupienie Konstantynopola w kwietniu 1204 roku w większym stopniu niźli wydarzenia z roku 1054, które były tylko jednym z wielu kryzysów w łonie chrześcijaństwa, doprowadziło do trwałego zerwania między ortodoksją i Kościołem rzymskim. Do bardzo wyrazistych obrazów grabieży, gwałtów 
i masakr, wyolbrzymionych niewątpliwie przez kronikarzy, dołączyły się jeszcze: podział Cesarstwa Bizantyjskiego pomiędzy zwycięzców, kradzież relikwii i niezręczne posunięcia Kościoła łacińskiego wprowadzonego przez krzyżowców na ziemiach greckich".

Próba „odwojowania” Bizancjum przez Kościół rzymski zaowocowała utworzeniem kilku państw - przede wszystkim Cesarstwa Łacińskiego (do 1261), księstwa Morei i rozbudową posiadłości rosnącej w potęgę Wenecji na Morzu Egejskim. Wszystkie te działania nie tylko osłabiły Bizancjum, ale przede wszystkim doprowadziły do ostatecznego rozejścia się chrześcijaństwa wschodniego z „łacinnikami”. $\mathrm{Z}$ punktu widzenia dziejów Europy jest to pierwszy tak głęboki rozłam jej jedności - od tego momentu mamy do czynienia z trwałym odziałem kontynentu, a w piśmiennictwie Zachodu pojęcie „chrześcijańskiej Europy" zarezerwowane zostaje wyłącznie dla wspólnoty katolickiej, co będzie miało swe poważne konsekwencje $\mathrm{z}$ chwilą pojawienia się na arenie politycznej Rosji z jej koncepcją pojmowania Moskwy jako „Trzeciego Rzymu”.

Warto też, niejako na marginesie tych rozważań, podkreślić, że wspierane przez Watykan trwające przez dwa stulecia wyprawy krzyżowe na trwałe wpisały się $\mathrm{w}$ świadomość wyznawców islamu, dla których przedstawiciele cywilizacji zachodniej po dzień dzisiejszy pozostają „krzyżowcami” stale gotowymi do unicestwienia ich religii i kultury, dla najbardziej zaś radykalnych wyznawców Proroka śmiertelnymi wrogami, wobec których uzasadniona jest każda przemoc. Okazuje się tutaj, że pozornie odległe w czasie i w zasadzie zatarte w świadomości współczesnych Europejczyków wydarzenia przez nich samych wywołane, trwają w głębokiej pamięci tych, dla których stanowią traumatyczny wymiar ich historycznego doświadczenia, co ma, oczywiście, często dramatyczne konsekwencje we wzajemnych relacjach.

Ale też nie od rzeczy będzie spostrzeżenie dotyczące dalszego biegu zdarzeń, a związane ze zdobyciem osłabionego Konstantynopola przez Turków w roku 1453. Sprawiło to, że muzułmanie zawładnęli kluczowymi drogami handlowymi wiodącymi na wschód, opanowując prak- 
tycznie cały basen Morza Czarnego. Skutki tego interesująco opisuje Arnold Toynbee.

Ta masywna islamska blokada dróg była wyzwaniem, które wywołało równie energicznq odpowiedź ze strony pionierskich wspólnot dwu zablokowanych społeczności chrześcijańskich. W świecie zachodniego chrześcijaństwa narody znad wybrzeża Atlantyku wynalazty $w X V$ w. nowy typ oceanicznego żaglowca: trójmasztowiec z osprzętem rejowym, najpierw z ożeglowaniem łacińskim, potem zaś ze sztakslem; żaglowiec mógt płynać catymi miesiacami bez zawijania do portu. Na takich statkach portugalscy marynarze, którzy odbyli swe próbne dalekomorskie rejsy [...] zdołali oskrzydlić arabski front morski na Atlantyku [...]. W okamgnieniu Portugalczycy wyrwali z rąk Arabów „talassokrację” na Oceanie Indyjskim ${ }^{18}$.

Tym samym można zasadnie stwierdzić, że jednym ze zgoła zaskakujących skutków wypraw krzyżowych stała się, za sprawą udoskonalonego sposobu żeglowania, rozpoczęcie w dziejach Europy zachodniej fazy podbojów kolonialnych. W stosunkowo krótkim czasie od upadku Konstantynopola do brzegów Ameryki dociera Krzysztof Kolumb, otwierając tym samym przed Europejczykami nowe przestrzenie zdobywane dzięki olbrzymiej przewadze technologicznej nad miejscowymi ludami podporządkowywanymi sobie przede wszystkim w imię ich chrystianizacji, jakkolwiek brutalnie wprowadzanej, lecz stanowiącej swego rodzaju moralne „usprawiedliwienie” dokonywanych gwałtów. Motywacja religijna, choć zapewne często traktowana czysto instrumentalnie, stanowiła jeden z ważnych impulsów ekspansji kolonialnej. Rywalizacja w tym obszarze podjęta została przede wszystkim przez te kraje europejskie, które dysponowały rozbudowaną flotą - były to zatem Anglia, Hiszpania, Portugalia, Holandia, Belgia i Francja, wśród przybyszy na nowe terytoria nie brakło zaś też licznych grup Włochów czy Niemców. Nie ulega też wątpliwości, że wśród kolonizatorów kraje Europy wschodniej pozostającej w orbicie oddziaływań Rzymu reprezen-

${ }^{18}$ Zob.: A. J. Toynbee, Studium historii, przeł. J. Marzęcki, Warszawa 2000. 
towane były przez grupy stosunkowo niewielkie, żaden zaś z tych krajów nie uczestniczył w podziale kolonialnych łupów, co w przyszłości w sposób oczywisty musiało wpłynąć na ich kondycję materialną i cywilizacyjną. Można zaryzykować tezę, że niemożność uczestniczenia krajów tego obszaru w procesie kolonialnym był jednym z istotnych choć dalece nie jedynym - czynników wpływających na zepchnięcie ich na peryferie Europy łacińskiej.

Z kolei po zajęciu Konstantynopola rozpoczyna się ekspansja turecka w obszarze bizantyjskim. Powstała w XIII stuleciu Turcja, po zjednoczeniu przez emira Osmana ludów pozostających na pograniczach Bizancjum ,w emiracie Osmana powstawały fanatyczne organizacje muzułmańskie dążące do podboju ziem chrześcijańskich w imię islamu. Potencjał ludzki nowego państwa tworzyli wolni chłopi tureccy, przeważnie należący do zachodniotureckiego ludu Oguzów, uciekający do emiratu Osmana przed pustoszącymi Iran i Azję Mniejszą Mongołami”.

W stosunkowo krótkim okresie rozwijające się dynamicznie Imperium Osmańskie opanowało tereny krajów bałkańskich, umacniając swe panowanie w trakcie walk z Węgrami, pieczętując swą przewagę zwycięstwem nad antyturecką koalicją w bitwie pod Warną w 1444, w trakcie której poległ król Polski i Węgier Władysław III Warneńczyk. W efekcie, po zajęciu Budy w roku 1541, Turcja stała się jednym z najpotężniejszych krajów w tym obszarze kontynentu podejmującym kolejne próby dalszej ekspansji powstrzymane ostatecznie po klęsce poniesionej $\mathrm{w}$ bitwie $\mathrm{z}$ koalicją zachodnioeuropejską pod Wiedniem $\mathrm{w}$ roku 1683, którą dowodził król Polski Jan III Sobieski. Niemniej panowanie na wcześniej zdobytych obszarach udało się jej utrzymać do końca XIX stulecia, a w istocie do upadku imperium osmańskiego.

Zarazem jednak trzeba podkreślić, że w całej przestrzeni dominacji Rzymu dokonywała się w średniowieczu integracja obejmująca przede wszystkim kraje określane dziś mianem Zachodu. Jednym z podstawowych czynników tej integracji była wszechobecność łaciny - dopiero epoka renesansu inicjuje na dobre rozwój piśmiennictwa w językach narodowych. Analizując ten stan rzeczy, pisze Ernst Curtius: 
Rozkwitanie literatur w językach wernakularnych, poczynajac od w. XII iXIII, nie oznacza wżadnym wypadku porażki ani ustępowania literatury łacińskiej. Odwrotnie - to właśnie te stulecia sa punktem szczytowym łacińskiej twórczości i nauki formułowanej po łacinie. W tym okresie język łaciński oraz twórczość, która $w$ nim uprawiano, rozciagnęty się „od Europy środkowej, poludniowej i pótnocnej aż po Islandię, Skandynawię $i$ Finlandię - aż po Palestynę". Zarówno człowiek wykształcony, jak i prosty wie, że istnieja dwa rodzaje języka: język potoczny i język literacki ludzi wykształconych (clerici, litterati). Ten właśnie język literacki bywat także określany jako grammatica, i dlatego Dante - podobnie jak przed nim rzymianin Varro - uważat go za język artystyczny, wynaleziony przez mędrców. Utwory pisane w językach miejscowych, ,,ludowych”, bywaty natomiast przekładane na łacinę. W ciagu nastepnych stuleci łacina pozostawała żywym językiem edukacji, uprawiania wiedzy, sprawowania wladzy oraz prawa i dyplomacji ${ }^{19}$.

Przy tym owa dominacja łaciny nie do końca blokuje powstawanie piśmiennictwa w językach ,ludowych”, na co zwrócił uwagę Erich Auerbach:

Istnieje bardzo stary uczony język, który ma jedynie fachowo wyksztatconych czytelników, ale mimo to, rozwijając się na różne sposoby, daje świadectwo rozkwitu intelektu i uczucia. Jednocześnie zaś istnieja języki wernakularne, które stopniowo uzyskuja pewność siebie; początkowo ograniczone calkowicie do opowiadania i oddawania uczuć, pod wieloma względami potrzebuja łacińskiej kurateli, jednakże postępujące wedtug własnych uwarunkowań i dźwigane przez inne, szersze warstwy, powoli się wybijaja $i$ wreszcie wykształcają sobie literacka publicznośćc ${ }^{20}$.

Jeszcze w XVI stuleciu owa wspólnota łacińska stanowiła naturalną przestrzeń literatury zachodnioeuropejskiej, sprawiając jednak, że za sprawą wypracowanych tu wzorców i chwytów utwory poszczególnych

${ }^{19}$ Zob. E. R. Curtius, Literatura europejska a łacińskie średniowiecze, przeł. A. Borowski, Kraków 1997.

${ }^{20}$ Zob. E. Auerbach, Język łaciński i jego odbiorcy w późnym antyku i średniowieczu, przeł. R. Urbański, Kraków 2006. 
pisarzy zatracały piętno indywidualna $\mathrm{i}$ - jak pisze Zygmunt Kubiak, podnosząc oryginalność twórczości obdarzonego w roku 1536 tytułem poeta laureatus Klemensa Janickiego - „poezja łacińska, tworzona w epoce renesansu we wszystkich niemal krajach Europy, nieraz wydaje się przygnieciona brzemieniem wspaniałych, przedwiecznych gór, brzemieniem, spod którego głos nowożytnego poety tylko niekiedy i niejasno się odzywa"21. Mamy tu zatem do czynienia ze zjawiskiem swoistej lingwistycznej uniformizacji, z procesem zatem, który znamionuje często schyłek formacji kulturowej zapowiadający jego przesilenie.

Schyłkowy też charakter zdaje się objawiać w początkach tego wieku także życie Kościoła katolickiego, czego objawami są problemy związane $\mathrm{z}$ tolerowaniem postaw odmiennych od narzucanych, coraz bardziej sztywnych reguł. Już wcześniej, w XIII i XIV stuleciu miał Kościół do czynienia $\mathrm{z}$ niemieszczącymi się $\mathrm{w}$ ustalonym porządku zjawiskami, jak choćby prezentacja poglądów mistrza Eckharta - czy szerzej: nie do końca mieszczących się w ramach ortodoksji poszukiwań mistyków, szczególnie na obszarach niemieckich. Eckhart, oskarżony o głoszenie tez niezgodnych z nauką Kościoła, postawiony został przed sądem kościelnym, którego wyrok zapadł już po śmierci podsądnego. Warto wszakże podkreślić, że kazania jego, spisane i wygłaszane w języku niemieckim, zostały surowo osądzone. Jak pisze Wiesław Szymona,

Eckhart [...] powolywat się ciagle na swoja dobra wiarę i z góry zdawat się na decyzję kurii, pewny pomyślnego dla siebie wyroku. Trybunat papieski o tyle wziat pod uwage jego postawe, że nie uznat go za formalnego heretyka. Przypisywane mu twierdzenia ocenit jednak nie w kontekście całej jego doktryny (z ta nikt się w Awinionie prawdopodobnie nie zapoznat, [...] lecz osadzit je wedlug materialnego brzmienia przethumaczonych (czy zawsze doktadnie?) na lacine (prout verba sonant) $i$ wszystkie uznat za heretyckie ${ }^{22}$.

${ }^{21}$ Zob. Z. Kubiak, Jak $w$ zwierciadle, Warszawa 1985.

${ }^{22}$ Zob. Mistrz Eckhart, Dzieła wszystkie, przeł. W. Szymona OP, Poznań 2013; zob. też: W. Szymona, Poznanie Boga w mistyce spekulatywnej Mistrza Eckharta, „Roczniki Filozoficzne" 2015, nr 63(2), s. 59-68. 
Jedno zdaje się nie ulegać wątpliwości - ramy wyznaczane przez ortodoksję instytucjonalną stawały się czynnikiem powodującym potęgowanie się kryzysu, którego istotę stanowiła instytucjonalizacja wartości. Ma rację Jan Józef Szczepański, gdy podkreśla: „Dawne kultury statyczne umierały lub upadały nagle $\mathrm{z}$ powodu nadmiernej jednorodności, z powodu niedostatku opcji, pobudzających proces poszukiwań i wyboru"23. Przy czym często bywa tak, że współcześni nie są świadomi tego stanu rzeczy, a podejmowane przez nich działania, nierzadko intuicyjne i będące reakcją na doraźne i w gruncie rzeczy marginalne zjawiska stają się momentem zwrotnym, za sprawą którego dochodzi do przesilenia. Taki też charakter miało wystąpienie Martina Lutra, które zapoczątkowało w Kościele ruch reformacyjny.

Luter $\mathrm{w}$ istocie nie był buntownikiem, wręcz przeciwnie - starał się podporządkować kościelnej hierarchii, z uwagą oddawał się lekturze Biblii, ale nie tylko w łacińskim przekładzie św. Hieronima, lecz także sięgając do wersji hebrajskiej, co już wykraczało poza kanon postępowania: ,Jego studia to Biblia, a celem - jasny jej tekst. Po to był mu potrzebny Reuchlinowski podręcznik hebrajskiego, po to greckie wydanie Nowego Testamentu, które niedawno ukazało się staraniem Erazma z Rotterdamu". Bez wątpienia też przetłumaczenie przezeń Pisma na język niemiecki - za czym poszły dalsze przekłady na języki narodowe stało się nie tylko ważnym przyczynkiem w rozwoju rodzimego języka literackiego, ale przede wszystkim dało szerokim warstwom społecznym możliwość konfrontacji treści kazań z przekazem Księgi, odarło więc częściowo kler z aury przysługującej „,wtajemniczonym”. Zarazem poszukiwania teologiczne w dziele Lutra zbiegają się z krytyką Kościoła instytucjonalnego, co trafnie podsumowuje Leszek Kołakowski:

Paradoksalność sytuacji Lutra zawiera się $w$ jego biografii, $w$ fakcie, że osobisty $i$ nader autentyczny szok religijny, który odsłonił mu prawdziwa naturę komunikacji człowieka z bóstwem, skoro wyrażony zostat $w$ doktrynie teologicznej, utrafit natychmiast, jak się okazało, w mase

${ }^{23}$ Zob. J. J. Szczepański, Nasze... 
żywotnych interesów niemieckiego społeczeństwa $i$ wynióst nieznanego mnicha na czoło wielkiego ruchu. [...] Przeżycie własnej niemocy i olśniewajace zrozumienie odrodzicielskiej sity wiary wlanej to byt akt pierwszy dramatu, ograniczony do jednostkowego sumienia religijnego. Idea usprawiedliwienia wiary to drugi akt, dziejacy się już $w$ zakresie dogmatu, teologii, rzeczywistości zreifikowanej, ale czysto teoretycznej. Reforma kościoła, który odtad pozwala jadać mięso $w$ piątek, nie domaga się pieniędzy za odpusty i msze prywatne i dopuszcza matżeństwo kapłanów - wszystko to stanowi akt trzeci i ostatni; kontynuacje poprzednich aktów, ale kontynuację $w$ świecie spolecznych antagonizmów $w^{24}$.

Ruch społeczny, dla którego impulsem stał się akt indywidualnego, osobistego przeżycia religijnego doprowadził w rezultacie do kolejnego po wielkiej schizmie roku 1054 - rozłamu jedności europejskiego Zachodu. Działania kontrreformacyjne stały się przyczyną pierwszej wielkiej wojny, którą można uznać za prefigurację późniejszych wojen światowych - wojny trzydziestoletniej z lat 1618-1648, która spustoszyła kontynent i której skutkiem stała się przyjęta wcześniej, po zakończeniu w Niemczech drugiej wojny religijnej między cesarzem Karolem V a książętami niemieckimi, zasada cuius regio eius religio. Wewnętrzne zróżnicowanie chrześcijaństwa przypieczętowane pokojem westfalskim stało się faktem, niemniej pozostawało ono nadal jednym z podstawowych - by nie powiedzieć głównym - wyróżników tożsamości europejskiej. Nie bez znaczenia też pozostaje fakt, że dramat tej kontynentalnej „,wojny domowej” - rozgrywającej się wszak nie tylko na płaszczyźnie religijnej: wystarczy wspomnieć także towarzyszące jej walki o wpływy kolonialne - nie dotyczył, z wyjątkiem Czech, obszarów Międzymorza, w tym Polski, w której jednak aktem banicji z roku 1658 zmuszono do emigracji arian, konstytucja sejmowa z roku 1668 zaś zakazywała porzucenia katolicyzmu. Jednocześnie jednym z istotnych skutków wojny trzydziestoletniej był wzrost potęgi Szwecji, która

${ }^{24}$ Zob. L. Kołakowski, Świadomość religijna a więź kościelna, Warszawa 1965. 
w tym okresie zyskała status mocarstwa i umocniła w obszarze swego panowania władztwo nad ziemiami Finlandii, które utraciła w XIX stuleciu na rzecz Rosji.

Równolegle do tych przemian na zachodzie kontynentu zachodziły przeobrażenia w jego części południowo-wschodniej, częściowo już poddanej panowaniu Turcji. W XVI stuleciu kształtować się poczęła potęga cesarstwa austro-węgierskiego. Powstrzymanie ekspansji tureckiej nastąpiło po zawarciu rozejmu między Węgrami i wezyrem Mehmedem Sokoloviciem w roku 1566. Bieg dalszych wypadków wyznaczyła polityka dynastii Habsburgów.

Proces zbliżenia chorwacko-słoweńskiego byt częścia ogólnego procesu przekształcania się austro-węgierskiej dynastii w unię realna. Coraz częściej zamiast do centralnych urzędów węgierskich rezydujących w Preszburgu (Bratysławie) Chorwaci odwotywali sie do centralnych urzędów wiedeńskich. Węgierska komora dworska już w 1548 roku podporządkowana została komorze wiedeńskiej, a założona w 1528 roku wegierska kancelaria dworska przeniesiona została $w 1531$ roku do Wiednia i następnie podporzadkowana tajnej radzie. Sprawami wojny kierowała wiedeńska wojskowa rada nadworna utworzona przez Ferdynanda I.

W rezultacie ziemie Słowian południowych oraz zachodnich już w XVI stuleciu praktycznie utraciły niezależny byt polityczny i podporządkowane zostały zwierzchności tureckiej i austro-węgierskiej.

Ruch reformacji, który doprowadził do rozłamania wspólnej dla Zachodu podstawy religijnej, ale też do przemian politycznych, był też zapowiedzią dalszych przeobrażeń, za sprawą których tożsamość poszczególnych krajów europejskich przestawała być definiowana przede wszystkim poprzez wyznanie. Przełom XVII i XVIII stulecia cechuje narastający kryzys europejskiej świadomości przekonująco opisany przez Paula Hazarda. Rozwój - przede wszystkim za sprawą pism Kartezjusza - myśli racjonalistycznej.

Nie zapominajmy - pisze Hazard - że w roku 1670 ukazat się Tractatus theologico-politicus (Traktat teologiczno-polityczny), który zawierat 
dostatecznie dużo nowości, żeby wstrzasnać społeczeństwem, do którego dotart. Spinoza spokojnie tłumaczyt po łacinie, że trzeba wykorzenić wszelkie tradycyjne wierzenia, by zaczać myśleć od nowa, na nowej płaszczyźnie; że doszło do takiego stanu rzeczy, kiedy nikt nie potrafi odróżnić chrześcijanina od Żyda, Turka czy poganina. Kiedy wiara przestała oddziaływać na moralność, dusza uległa zepsuciu. Zło jest nastepstwem faktu, że religia nie opiera sie już na rozważnym i dobrowolnym akcie wewnętrznym, lecz na kulcie zewnętrznym, na mechanicznych praktykach, na biernym poddaniu się zaleceniom księży $y^{25}$.

Postępujący kryzys instytucji religijnych - zarówno Kościoła katolickiego, jak i protestanckich - otwierał perspektywy nowego ich usytuowania w strukturach państw zachodnioeuropejskich, przede wszystkim we Francji. Ów kryzys wszakże nie był jedynym symptomem zachodzących przemian. Na inny zwrócił uwagę w opublikowanym anonimowo w 1798 roku An Essay on the Principle of Population ekonomista Thomas Malthus, zapowiadając, że tempo przyrostu naturalnego musi doprowadzić w Europie do klęski głodu i wzrostu ubóstwa. Przyrost naturalny na kontynencie w wieku XVIII rzeczywiście mógł swą gwałtownością wzbudzić tego rodzaju obawy - w ciągu stulecia liczebność populacji w Europie wzrosła o 58\%. Na uwagę zasługuje zwłaszcza przyrost mieszkańców miast - ludność Londynu powiększa się z 500 tys. do miliona, Paryża z 400 tys. do 600 tys. Można więc zaryzykować tezę, że licząc od rewolucji francuskiej w 1789 roku - przy czym należy tę datę traktować jako wyznacznik symboliczny - w Europie, szczególnie w jej zachodnich krajach, rozpoczynają się kształtować struktury społeczeństw masowych.

Dotychczasowy, religijny przede wszystkim wyznacznik tożsamości powoli zaczyna być zastępowany przez identyfikację narodową. Zaczynają się krystalizować - często za sprawą literatury - struktury państw narodowych pozwalające na scalenie dotąd rozczłonkowanych,

${ }^{25}$ Zob. P. Hazard, Myśl europejska XVIII wieku. Od Monteskiusza do Lessinga, przeł. H. Suwała, Warszawa 1972; zob. też idem, Kryzys świadomości europejskiej 1680-1715, przeł. J. Kalewicz, A. Siemek, Warszawa 1974. 
jak choćby Włochy i Niemcy, krajów. „Ktokolwiek nie uprzedzony czyta niemiecką produkcję liryczną pleniącą się bujnie w połowie stulecia, dziwi się spotykając w tylu odach bakchicznych, anakreontycznych, moralizujących i innych aluzje do dumnych Germanów, do ich siły, męstwa i niezależności, ubolewania nad uciśnioną dzisiaj Germanią, wołanie o jedność. Wszyscy ci poeci w niezręcznej jeszcze formie wyrażają to samo, narodowe już, uczucie, które wszędzie dochodzi do głosu, i uczucie to skrystalizuje się wokół osoby Fryderyka [Wielkiego]. Pieśni pruskiego grenadiera zebrane przez Gleima w 1758 roku nie są arcydziełem, ale można w nich dostrzec przejście od idei Prus do idei Niemiec. Gleim, przybierając postać żołnierza, wojownika, oświadcza, że nie jest ani Pindarem, ani Horacym: jest nowożytnym Tyrteuszem".

W ogarniętej rewolucją Francji pojawia się - w wydawanym przez Réne Hérberta piśmie „Le pére Duchesne” idea dechrystianizacji kraju i utworzenia państwa świeckiego. Zarazem w Anglii publikacja Rozważań o rewolucji francuskiej Edmunda Burke'a staje się swego rodzaju manifestem doktryny konserwatyzmu. Niezależnie od tego upowszechniała się idea absolutyzmu oświeconego wspierana przez takich władców jak Fryderyk Wielki czy królowie skandynawscy, po części akceptowana w Rosji, przynajmniej w sferze deklaracji osobistych, przez carycę Katarzynę II. Termin ten, wprowadzony przez Pierre'a Paula Lemerciera, zyskał popularność w XIX stuleciu. Impulsem do tych wszystkich poszukiwań stało się ogłoszenie w roku 1776 deklaracji niepodległości przez Stany Zjednoczone Ameryki. O ile jednak w USA to wydarzenie oznaczało początek budowy struktur państwa obywatelskiego, o tyle w Europie dominować zaczął nurt narodowy, który z czasem uzupełniony został przez komponent rasistowski, w tym szczególnie antysemicki: ,teoretyczne” podstawy dały tu takie prace jak czterotomowe opracowanie Hustona Stewarta Chamberlaina Die Grundlagen des XIX Jahrhunderts (1853-1855) oraz Josepha Artura Gobineau Szkice o nierówności ras ludzkich (1899). Komentując ten stan rzeczy, Golo Mann pisał: 
Dał o sobie znać obłęd rasowy. Panowanie było jakoby przeznaczeniem białych, już to wszystkich, już to w szczególności ludów germańskich: Amerykanów, Brytyjczyków, Niemców. Rhodes, zdobywca Afryki Poludniowej wyznawat ten pogląd z cała dobitnościa. Odbił on się echem w Niemczech. Cesarz pót-Anglik z urodzenia, który darzył ojczyznę swojej matki petna podziwu, nienawistna miłościa, kazat sobie powiesić nad biurkiem hymn Kiplinga sławiacy władzę i sukces. Namiętnie czytywat pisma Hustona Stewarta Chamberlaina, Niemca z wyboru, który głosit wyższość rasy nordyckiej $i$ utrzymywat, że Zbawiciel byt Germaninem ${ }^{26}$.

Najgłośniejszym przykładem rasistowskiego obłędu pod koniec XIX stulecia stała się we Francji sprawa oficera artylerii Alfreda Dreyfusa oskarżonego w 1894 roku o zdradę na rzecz Niemiec. Zapewne nie miałaby ona tak wielkiego odzewu społecznego, gdyby nie narastający antysemityzm wywołany przez bankructwo w 1885 roku związanego z Kościołem Union Générale konkurującego z pozostającymi w dominacji francuskich Żydów instytucjami finansowymi czy przez wydaną w 1886 roku książkę Dumonta La France Juive. W akcję obrony Dreyfusa włączył się artykułem Oskarżam! pisarz Emil Zola.

To jedynie przykłady wzmagających się w Europie postaw narodowych wyradzających się w nacjonalistyczne. Wiek XIX bez wątpienia można określić jako czas tworzenia i umacniania się struktur państw narodowych i czynienia z identyfikacji narodowej fundamentu postaw tożsamościowych. Ich upowszechnianie się wzmacniała XIX-wieczna eksplozja demograficzna i związany z nią w krajach zachodnioeuropejskich - także za sprawą industrializacji i urbanizacji oraz rozwoju oświaty - wzrost liczby uczestników życia społeczno-politycznego. Analizując skutki tych procesów w latach dwudziestych XX wieku Marceli Handelsman, podkreślał:

W miarę rozszerzania się świadomości i ilościowo, i jakościowo, ludowość wypetnia cała szerokość życia narodowego. Nie ma w nim miejsca dla nikogo poza ludem i albo trzeba weń wejść całkowicie, albo jest się

${ }^{26}$ Zob. G. Mann, Niemieckie zieje XIX i XX wieku, przeł. A. Kopacki, Olsztyn 2007. 
wyrzuconym poza jego ramy. I to właśnie jest udziałem warstw, które poprzednio reprezentowaty państwo i jego ideologię. Nie bez walki zmuszone sa one przyjąć zmiany dokonane, a przekonawszy się o niemożności odwrócenia biegu dziejów wchodza one z powrotem do narodu, by przejąwszy jego nowa ideologię, zając w nim ponownie miejsce dominujące. Takim jest schemat rozwoju w życiu narodów posiadajacych państwo własne, takim jest on $w$ gruncie rzeczy i dla narodów niepaństwowych [...]. Zmiana ta nie dokonywa się nigdzie sposobem dobrowolnego ustapienia pozycji zajmowanych przez warstwy uprzywilejowane, lecz jest rezultatem przewrotu, bądź wynikiem rewolucji, jak we Francji, bądź skutkiem zmian gwaltownych, zwanych zresztą reformami, jak to miało miejsce w Europie środkowej $w$ promieniu wojen napoleońskich i dojrzewania przekształceń 1848 roku, bądź wreszcie pochodna przekształceń politycznych, jak to się stało po zawaleniu caratu z narodami, wyzwolonymi spod jego jarzma ${ }^{27}$.

I rzeczywiście, rok 1848, w którym mamy do czynienia z Wiosną Ludów, zdaje się mieć znaczenie dla tego procesu przełomowe. Jeśli przyjąć, że przemiany społeczne, za sprawą których dotychczas funkcjonujące w Europie civitas Dei (cuius regio, eius religio) poczęło się przekształcać w civitas homini, wówczas przeobrażenia, jakie zaszły w XVIII i pierwszej połowie XIX stulecia, wyniosły na plan pierwszy pojęcie narodu, które wszakże okazało się dwojakie: z jednej strony jak w USA - mamy do czynienia ze społeczeństwem wolnych obywateli, z drugiej zaś - co tyczy Europy - z tworzącymi naród masami. Właśnie podczas wydarzeń Wiosny Ludów takie pojęcie wspólnoty okazało się - być może za sprawą rozpowszechnionych w Europie idei romantycznych dominujące. Przy czym warto podkreślić, że pierwiastek religijny przestał tu odgrywać istotną rolę - stał się jedynie swego rodzaju oczywistością: kwestia wiary (po części także wyznania) delegowana została, co oczywiście musiało budzić wątpliwości chrześcijan, w szczególności zaś katolików, do decyzji poszczególnych osób.

Niezależnie od tego wydarzenia Wiosny Ludów stały się momentem, w którym Międzymorze pojawiło się na mapie Europy jako wy-

${ }^{27}$ Zob. M. Handelsman, Rozwój narodowości nowożytnej, Warszawa 1973. 
odrębniona całość. Po rozbiorach Polski ta część kontynentu znalazła się pod władztwem obcych potęg: Turcji, Rosji oraz Austro-Węgier. Wiele powstań narodowych podejmowanych w roku 1848 zmierzało do odzyskania przez te kraje politycznej podmiotowości, odzyskania czy pozyskania bytu politycznego. Masy ludowe - jakkolwiek ten termin rozumieć - stały się mniej lub bardziej świadomym czynnikiem zachodzących przemian, do czego przyczynił się rozwój czytelnictwa prasy i upowszechnianie za jego pośrednictwem masowych ideologii.

Struktura społeczeństwa masowego, stanowiącego czynnik decydujący o biegu przemian, wciąż nie jest, moim zdaniem, dostatecznie rozpoznana. Być może nie wystarczą tu badania socjologiczne czy politologiczne, a trzeba się odwołać raczej do pewnych intuicji poetyckich, jak choćby do eseju Eliasa Canettiego Masa $i$ władza, w którym zastanawiając się nad własnościami masy, pisze:

Masie potrzebny jest kierunek. Znajduje się ona w ruchu i porusza się w kierunku czegoś określonego. Kierunek, wspólny wszystkim jej członkom, wzmacnia poczucie równości. Wspólny cel, znajdujący się poza wszystkimi członkami masy, zmiata z powierzchni ziemi ich prywatne, zróżnicowane cele, które bylyby śmiercia masy. Kierunek jest niezbędny dla jej istnienia. Zawsze żywa obawa przed rozpadem umożliwia ukierunkowanie jej na określone cele. Masa istnieje, dopóki ma przed soba nie osiagnięty cel. Zaznacza się w niej jednak również mroczna tendencja do ruchu, rodzacego nowe, nadrzedne powiazania. Charakter tych tworów często nie da się z góry przewidzieć ${ }^{28}$.

Warto przy tym podkreślić, że nowożytne społeczeństwa, będące społeczeństwami masowymi, są zarazem tworzone przez zespoły mas, $\mathrm{z}$ których każda porusza się w innym kierunku, co siłą rzeczy musi prowadzić do konfliktów wewnętrznych, mających przede wszystkim wymiar ideologiczny. Rzecz w tym, że same nie będąc czynnikiem sprawczym, masy stanowią nieusuwalny - napędzany emocjami - nośnik energii umożliwiającej zmierzanie do osiągnięcia celów. Ten me-

${ }^{28}$ Zob. E. Canetti, Masa i władza, przeł. E. Borg, M. Przybyłowska, Warszawa 1996. 
chanizm funkcjonował w XIX-wiecznych krajach europejskich. Trafnie opisany został przez niemieckiego historyka, wybitnego badacza antycznego Grecji i Bizancjum, Ferdynanda Gregoroviusa, w jego komentarzu do zrywu narodowego Polaków w Wielkopolsce w roku 1848:

Jeśli poprzednio stwierdziliśmy, że sprawy Polski, tego okrutnie uciskanego, szlachetnego narodu jest sprawa całej Europy, to potwierdzity to dobitnie zaistniałe tymczasem wydarzenia. Cała Europe od Tamizy do Morza Śródziemnego, od Sekwany do Dunaju przemierzaja polscy emisariusze wzburzajac ja $i$ wprowadzając w zamęt. Niemal każde drgnięcie w poszczególnych krajach potegowane jest rozpaczliwym wysitkiem tego narodu, który jak marna roślina skalna przywiera swymi mocno trzymającymi się korzeniami do twardego, skamieniałego serca polityki, ale zapuścit swe głębokie rozłogi $w$ bardziej miękkie serce narodów. Emigracji nie sposób zwyciężyć. Ona korzysta z wszystkich namiętności narodów, wciska się w sam środek ich zabaw publicznych jako ten duch, który zakłóca spokój $i$ wiecznie będzie bładził, dopóki wina jego nie będzie odpokutowana a żądaniom jego nie uczyni się zadośćc 29.

Mamy tu do czynienia z komentarzem świadka epoki śledzącego mechanizmy zachodzących procesów historycznych i mającego świadomość doniosłości wydarzeń europejskiej Wiosny Ludów w kształtowaniu się nowego ładu społeczno-politycznego. Ważniejsze wszakże wydaje się tutaj wskazanie przez Gregoroviusa owej „,idei polskości”, której upatrywał w republikanizmie wzorowanym na antyku, zaś wskazując przyczyny upadku kraju podkreślał: „Wolne państwo polskie [...] pominęło niezbędne składniki podziału stanowego i państwa praworządnego, było dlatego połowiczne, było republiką bez demokracji" Odwołanie się do praworządności i demokracji jako warunków, których spełnienie umożliwia urzeczywistnienie suwerennego bytu politycznego, jest tu najbardziej precyzyjnym rozpoznaniem istoty przeobrażeń, których symbolem stała się rewolucja francuska.

\footnotetext{
${ }^{29}$ Zob. F. Gregorovius, Idea polskości, przeł. F. Jeziołowicz, Olsztyn 1991. ${ }^{30}$ Ibidem.
} 
W procesie przekształceń życia społecznego i politycznego Europa wkroczyła wówczas - za sprawą jednoczesnej eksplozji demograficznej oraz przyspieszenia i upowszechnienia rozwoju nauk, zarówno technicznych, przyrodniczych jak humanistycznych, a wreszcie procesom urbanizacji i industrializacji - w całkowicie nową fazę. Dotyczyło to wszakże przede wszystkim społeczności krajów politycznie suwerennych, posiadających kolonie, zdolnych do prób tworzenia demokratycznych instytucji. Przy czym owe przekształcenia nie dokonywały się skokowo i bez konfliktów - by wspomnieć tylko angielski ruch niszczycieli maszyn z początku XIX stulecia - lecz miały charakter ewolucyjny. Przy czym warto zauważyć, że, co trafnie pochwycił Toynbee, przeobrażenia te mają swe głębsze korzenie.

[A]ngielski wyczyn przelania nowego wina administracyjnej sprawności renesansowych Włoch w stare butle średniowiecznego transalpejskiego parlamentaryzmu - i niedopuszczenie do ich pęknięcia - jest ustrojowym triumfem, który można tylko uznać za coś zdumiewajacego. I ten angielski ustrojowy tour de force przeprowadzenia parlamentu przez przepaść, jaka oddziela krytykę rzadu od sprawowania rzadu, zostat dokonany na użytek zachodniej społeczności przez angielska twórcza mniejszość $w$ pierwszej fazie jej wycofania się z uwikłań kontynentalnych: okresie obejmujacym epoke elżbietańska i większa część XVII w. Gdy, w odpowiedzi na wyzwanie ze strony Ludwika XIV, Anglicy dokonali częściowego ii chwilowego powrotu na arenę kontynentalna [...], narody kontynentalne poczęly zwracać uwagę na poczynania wyspiarzy. Nastała epoka Anglomanie, jak zwali ją czasami Francuzi. [...] Anglomanie, w formie kultu monarchii konstytucyjnej, była jednym z punktów zapalnych, które wznieciły pożar Rewolucji Francuskiej, i jest rzecza powszechnie znana, że gdy XIX w. przełamywat się $w X X$ w. wszystkie narody ziemi zostaty opętane ambicja, by przesłonić swa polityczna nagość parlamentarnymi listkami figowymi ${ }^{31}$.

Parlamentaryzm mógł się jednak rozwijać wyłącznie w krajach posiadających byt polityczny lub co najmniej częściową polityczną

${ }^{31}$ A. J. Toynbee, Studium ... 
autonomię. Jednocześnie tu właśnie, w państwach suwerennych i w ich parlamentach kształtować się poczęły i zyskiwać instytucjonalne formy idee praw i wolności obywatelskich, których stanowienie podłożyło podwaliny państwowości tworzonych w głównej mierze przez europejskich przybyszy Stanów Zjednoczonych - nie jest też przypadkiem, że w tworzenie tych fundamentów angażowali się tacy europejscy ochotnicy, jak La Fayette, von Steuben, Kościuszko czy Pułaski, nie przypadkiem też w stulecie niepodległości USA właśnie Francuzi zaprojektowali Statuę Wolności i podarowali ją Amerykanom.

W poszukiwaniach korzeni nowożytnej idei państwa prawa z pewnością za istotny punkt odniesienia uznać należy filozoficzne dzieło Johna Locke’a, w szczególności jego ogłoszony w 1689 roku List o tolerancji, w którym - nie bez inspiracji pismami wygnanymi z kraju polskich arian osiadłych w Niderlandach - postulował zasady tolerancji religijnej wspartej na rozdziale instytucji religijnych od państwa: dość wspomnieć zgłaszający podobny postulat, ogłoszony w 1628 roku traktat Samuela Przypkowskiego Dissertatio de pace et concordia ecclesiae. Po części z tego źródła, obok rozwoju oświeceniowej filozofii we Francji, wywodzi się ogłoszona sto lat później Deklaracja Praw Człowieka i Obywatela. Powoli też kształtuje się praktyka demokratycznego państwa prawa - począwszy od opracowanego przez Monteskiusza trójpodziału władz, o którym mowa w opublikowanym w roku 1748 dziele $O$ duchu praw, po ogłoszoną sto lat później pracę Alexisa de Tocqueville'a $O$ demokracji w Ameryce.

O ile jednak w USA kwestia państwa narodowego jako wyzwanie ideologiczne w zasadzie pozostaje nieobecna, o tyle w wieku XIX i w pierwszej połowie XX stulecia problem ten należy w sprawczych obu wojen światowych i doprowadzając do paroksyzmu nacjonalistycznych praktyk, jakim stała się Zagłada Żydów wsparta pseudonaukową publicystyką Alfreda Rosenberga odwołującego się w swym Micie dwudziestego wieku do teorii rasistowskich Gabineau i Chateaubrianda.

Można zaryzykować tezę, że to doświadczenie stało się jednym z kluczowych w kształtowaniu zasad tworzenia po wojnie współcze- 
snych liberalnych państw prawnych Europy Zachodniej. Ma też zapewne rację Lyotard, gdy pisze:

Co do mnie twierdze, że nowoczesny projekt (urzeczywistnienia uniwersalności) nie zostat zarzucony, zapomniany, lecz niszczony, ,zlikwidowany”. Istnieje wiele odmian destrukcji $i$ wiele nazw będacych jej symbolami. Można przyjąć „Auschwitz” jako nazwę paradygmatyczna, odnosząca się do tragicznego ,niedokończenia” nowoczesności ${ }^{32}$.

„Auschwitz” bez wątpienia nie tylko można, ale należy przyjąć jako określenie doświadczenia granicznego. Trudno przecenić rolę USA, które za sprawą wprowadzenia w Niemczech Zachodnich zasad nowożytnego państwa prawa i doprowadzając do sytuacji, w której (zachodnio)niemiecka tożsamość opisana została przez socjologów terminem Verfassungsidentität - a tym samym oczyszczona z kontekstów nacjonalistycznych - doprowadziły do przekształcenia tego państwa o największym potencjale ekonomicznym w Europie Zachodniej w kraj, którego tożsamość określona została przez zasady prawa konstytucyjnego, a nie odniesienia ideologiczne. Zarazem ten właśnie potencjał - wsparty przez zastrzyk amerykańskiego kapitału zaaplikowany Europie Zachodniej przez plan Marshalla, który został odrzucony przez Stalina i satelickie kraje Sowietów - stworzył podstawy wspólnoty, która wyewoluowała w Unię Europejską.

Nim jednak do tego doszło Europa poddana została serii szybkich przemian - po zakończeniu drugiej wojny światowej obalone zostały trzy najpotężniejsze cesarstwa - rosyjskie, austro-węgierskie oraz pruskie, co doprowadziło do pozyskania bytu politycznego przez szereg krajów dotąd tego bytu pozbawionych - krajów bałtyckich z Finlandią i krajów Europy Środkowo-Wschodniej. Powstanie Związku Sowieckiego oznaczało utworzenie pierwszego ideologicznego mocarstwa totalitarnego, w 1933 roku Niemcy, za sprawą dominacji ideologii narodowosocjalistycznej, wyrosły na kolejne mocarstwo tego typu. Starcie

${ }^{32}$ Zob. J. F. Lyotard, Postmodernizm dla dzieci, przeł. J. Migasiński, Warszawa 1998. 
obu tych ideologicznych potęg sprawiło, że znaczna część kontynentu między Rosją i Niemcami w czasie wojny doświadczyła obu totalitaryzmów, po oddaniu zaś Sowietom po rozgromieniu Niemiec władztwa nad środkową częścią kontynentu doprowadziło do jego pół wieku trwającego podziału. Rozpoczęty w 1980 roku w Polsce proces wyzwalania się z komunizmu, zakończony w roku 1989 otworzył perspektywę - za sprawą rozszerzania Unii Europejskiej o nowych członków - budowy, w oparciu o przyjmowane przez wyzwolone kraje zasady liberalnego państwa prawa nowej, zakładającej rozwiązywanie konfliktów w drodze pozyskiwania konsensu, wspólnoty.

\section{Bibliografia}

Amgold M., Czwarta krucjata, przeł. B. Spieralska, Warszawa 2006.

Auerbach E., Język łaciński $i$ jego odbiorcy w późnym antyku $i$ średniowieczu, przeł. R. Urbański, Kraków 2006.

Balard M., Łaciński Wschód XI- $X V w$., przeł. W. Ceran, Warszawa 2010.

Bocheński J., Niepodległość wśród ludzkości, „Zapis” 1978, nr 8.

Canetti E., Masa i władza, przeł. E. Borg, M. Przybyłowska, Warszawa 1996.

Chadwick H., Kościót w epoce wczesnego chrześcijaństwa, przeł. A. Wypustek, Warszawa 2004.

Curtius E. R., Literatura europejska a tacińskie średniowiecze, przeł. A. Borowski, Kraków 1997.

Davies N., Europa. Rozprawa historyka z historia, przeł. E. Tabakowska, Kraków 1998.

Dawson Ch., Szkice o kulturze średniowiecznej, przeł. J. Sułkowski, Warszawa 1966.

Domenach J. M., Europa: wyzwanie dla kultury, przeł. H. Sikorska, Warszawa 1992.

Eckhart, Dzieła wszystkie, przeł. W. Szymona OP, Poznań 2013.

Friedenthal R., Marcin Luter. Jego życie i czasy, przeł. C. Tarnogórski, Warszawa 1992.

Gregorovius F., Idea polskości, przeł. F. Jeziołowicz, Olsztyn 1991.

Guriewicz A., Problemy średniowiecznej kultury ludowej, przeł. Z. Dobrzyński, Warszawa 1987.

Handelsman M., Rozwój narodowości nowożytnej, Warszawa 1973. 
Hazard P., Kryzys świadomości europejskiej 1680-1715, przeł. J. Kalewicz, A. Siemek, Warszawa 1974.

Hazard P., Myśl europejska XVIII wieku. Od Monteskiusza do Lessinga, przeł. H. Suwała, Warszawa 1972.

Kantorowicz E. H., Dwa ciała króla. Studium średniowiecznej teologii politycznej, przeł. M. Michalski, A. Krawiec, Warszawa 2007.

Kawafis K., Wiersze zebrane, przeł. Z. Kubiak, Warszawa 1992.

Kłoczowski J., Nasza tysiącletnia Europa, Warszawa 2010.

Kołakowski L., Świadomość religijna a więź kościelna, Warszawa 1965.

Kubiak Z., Jak w zwierciadle, Warszawa 1985.

Kwiatkowski S., Średniowieczne dzieje Europy, Warszawa 2006.

Lyotard J. F., Postmodernizm dla dzieci, przeł. J. Migasiński, Warszawa 1998.

Mann G., Niemieckie dzieje XIX i XX wieku, przeł. A. Kopacki, Olsztyn 2007.

Mechtylda z Magdeburga, Strumień światta, przeł. P. J. Nowak, Tyniec-Kraków 1999.

Modzelewski K., Barbarzyńska Europa, Warszawa 2004.

Weizsäcker C. F., Czas, fizyka, metafizyka, przeł. K. Napiórkowski [w:] Człowiek w nauce wspótczesnej. Rozmowy w Castelgandolfo, red. K. Michalski, Paris 1988.

Skowronek J., Tanty M., Wasilewski T., Stowianie południowi i zachodni VI-XX wiek, Warszawa 2005.

Smith J. M. H., Europa po Rzymie. Historia kulturowa lat 500-1000, przeł. A. Cwojrak, Kraków 2008.

Szczepański J. J., Nasze nie nasze, Kraków 1984.

Szymona, W., Poznanie Boga w mistyce spekulatywnej Mistrza Eckharta. „Roczniki Filozoficzne" 2015, nr 63, 2, s. 59-68.

Toynbee A. J., Studium historii, przeł. J. Marzęcki, Warszawa 2000.

\section{Identity of Intermarium - West}

The presented text is an introduction to the study of the formation of the Intermarium, which in the 19th and 20th centuries included countries that lacked political existence or had limited sovereinty. This fact has now conditioned the identity of these peoples in the space between Western democracy and Russian autocracy. The peoples of the Intermarium were under the dominance of other countries, so they did not participate in the formation of modern nation-states in the 19th century. The text is an attempt 
to outline the formation of the political system of Western Europe (Latin), which constituted the starting point for the countries of the Intermarium in creating their own political systems (after 1989).

Keywords: Intermarium, cultural identity, national identity, cultural processes 